\title{
Floristic composition of Melastomataceae between reforested and natural areas in the Recife Atlantic Forest, Pernambuco, Brazil
}

\author{
Yuri de Souza Vieira Couceiro \\ Jefferson Rodrigues Maciel * \\ Jardim Botânico do Recife \\ Km 7,5 da BR 232, s/n, Curado, CEP 50.000-230, Recife - PE, Brazil \\ * Autor para correspondência \\ jeffersonmaciel@recife.pe.gov.br
}

Submetido em 19/10/2020

Aceito para publicação em 17/12/2020

\section{Resumo}

Florística de Melastomataceae entre áreas reflorestada e natural na Mata Atlântica de Recife, Pernambuco, Brasil. A extinção local de espécies da flora nativa da Floresta Atlântica ocorre, principalmente, devido à fragmentação de habitats. Reflorestamento e a regeneração natural podem mitigar esses fatores. Neste estudo, procuramos entender se a composição florística e os processos de dispersão estão sendo restabelecidos em uma área de Floresta Atlântica de terras baixas oito anos após seu reflorestamento. A área de estudo foi um antigo pasto entre dois fragmentos urbanos na cidade do Recife que foi reflorestado em 2011. Espécies de Melastomataceae foram coletadas e a morfologia dos seus frutos foram comparadas com as espécies da família em fragmentos adjacentes. Miconia prasina, M. albicans, M. affinis, Clidemia hirta, and C. capitellata foram encontradas na área reflorestada. Embora nos fragmentos adjacentes existam espécies com frutos maiores, não houve diferença estatisticamente significativa entre as médias das duas áreas. A morfologia dos frutos indica que as espécies encontradas na área são dispersas por aves e pequenos mamíferos. É possível concluir que a área reflorestada já apresenta processos ecológicos esperados para um corredor entre dois fragmentos e que as duas áreas adjacentes servem como vetores para colonização de espécies nativas da Floresta Atlântica na área reflorestada.

Palavras-chave: Clidemia; Conservação; Dispersão; Jardim botânico; Miconia; Regeneração

\section{Abstract}

Local extinction of native Atlantic Forest flora species occurs mainly due to habitat fragmentation. Reforestation and natural regeneration can mitigate these factors. The present study attempts to understand whether floristic composition and dispersal processes are being reestablished in an area of lowland Atlantic Forest, eight years after its reforestation. The study area was an old pasture set between two urban fragments in the city of Recife that was reforested in 2011. Melastomataceae species were collected in this area and the morphology of their fruits was compared with the species of the family recorded in the adjacent fragments. Miconia prasina, M. albicans, M. affinis, Clidemia hirta, and C. capitellata have been found in the reforested area. Although there are species with larger fruits in the adjacent fragments, there was no statistically significant 
difference between the means of the two areas. The fruit morphology indicates that the species found in the area are dispersed by birds and small mammals. It is possible to conclude that the reforested area already presents the expected ecological processes for a corridor between two fragments. Thus, the two adjacent areas serve as vectors for the colonization of native Atlantic Forest species in the reforested area.

Key words: Clidemia; Conservation; Dispersion; Miconia; Regeneration

\section{Introduction}

Forest fragmentation is one of the main processes responsible for species extinction and the destruction of ecosystems (RIBEIRO et al., 2009), and is defined as the process of reducing a continuous landscape into subunits that differ from their matrix (FAHRIG, 2003). Fragmentation has profoundly affected the Atlantic Forest, originally the second largest rainforest in the Americas, spanning the Brazilian coast into Argentina and Paraguay and covering approximately 1.5 million $\mathrm{km}^{2}$ (RIBEIRO et al., 2009). The Atlantic Forest is one of the main hotspots of biological diversity due to the drastic reduction of its original area and a great number of endemic species (MYERS et al., 2000; MITTERMEIER et al., 2003). Today, Atlantic Forest vegetation remains between $7 \%$ and $15 \%$ of its original coverage (RIBEIRO et al., 2009; REZENDE et al., 2018), while the north of the São Francisco River retains only $2 \%$ of its original vegetation (TABARELLI et al., 2006; RIBEIRO et al., 2009; REZENDE et al., 2018).

Successional changes affect species composition (LIEBSCH et al., 2008). Secondary successional stages favor pioneer and weedy species as a consequence of changes in light availability and temperature of microhabitats (OLIVEIRA et al., 2004; TABARELLI et al., 2004). During the natural regeneration process, a gradual replacement of small fruit species with larger fruit species is also expected (TABARELLI; PERES, 2002). Areas with a short recovery time present a predominance of species with fruit size that is considered small (on average $0.6 \mathrm{~cm}$ ) and, as the area matures, there is a gradual substitution with larger fruit species (on average $1.5 \mathrm{~cm}$ ) (TABARELLI; PERES, 2002). Based on these premises, one might expect that recently reforested areas present a predominance of small-fruited pioneer species in the understory.
Melastomataceae has about 4,500 species distributed in 150 genera that occur in tropical and subtropical zones worldwide (GOLDENBERG, 2012). In Brazil, the family is represented by ca. 1,450 species classified in 69 genera, with Miconia Ruiz \& Pav., Leandra Raddi, and Tibouchina Aubl. as the richest genera (GOLDENBERG, 2012; FLORA DO BRASIL, 2020). The species occur in all of Brazil's phytogeographic domains, and are especially diverse in the Atlantic Forest, with about 560 species (FLORA DO BRASIL, 2020), including endemic genera such as Bertolonia Raddi and Eriocnema Naudin (BFG, 2015; BACCI et al., 2018; FLORA DO BRASIL, 2020). Their species can disperse the seeds through biotic or abiotic vectors (REGINATO et al., 2020). When biotically dispersed, the species present fleshy berries that are dispersed by frugivorous birds and mammals (REGINATO et al., 2020).

Floristic studies have recorded 6 to 17 species of Melastomataceae in the Atlantic Forest remnants of the state of Pernambuco (MELO et al., 2011; CAVALCANTI et al., 2016). During the early stages of forest regeneration, Melastomataceae is the dominant family among small-sized fruit species from the Atlantic Forest above the São Francisco River (TABARELLI; PERES, 2002). Some studies reported that birds and marmosets consume fruits of the Melastomataceae species, confirming the importance of this family to the region's fauna (PONTES; SOARES, 2005; ALVES, 2014). This evidence reinforces the important role that the Melastomataceae plays in the Atlantic Forest above the São Francisco river, whether as a dominant element in the physiognomy, as a species-rich family, or as a source of food resource to the fauna.

In the present study, we investigate whether the floristic composition and dispersal processes are being reestablished in an area of lowland Atlantic Forest 
eight years after reforestation. We expect to find a predominance of pioneer species of Melastomataceae in the understory of a reforested patch of Atlantic Forest since recently reforested areas could present similar dynamics to recently disturbed areas. Furthermore, if ecological processes are being reestablished, we will find a predominance of biotic dispersed species.

\section{Materials and Methods}

\section{Study area}

The area of study (reforested area-RA) is located in an intensely urbanized matrix that is part of the Curado District in Recife, Pernambuco, Brazil ( $8^{\circ} 04^{\prime} 40.9^{\prime \prime}$; $\left.34^{\circ} 57^{\prime} 53.0^{\prime \prime} \mathrm{W}\right)$, which is flanked by two remnants of the Lowland Atlantic Forest with areas of 9 and 30 ha (Matas do Curado - MC; Figure 1). It is adjacent to the Recife Botanical Garden in its western portion; in the southern portion is bordered by the Jardim Botânico Residential Complex, separated only by a wall; a fragment of the Atlantic Forest presenting the physiognomy of a mature fragment lies in the eastern portion, and is used by the surrounding communities, ; and the former Foundation of the Shopkeepers Club of Pernambuco, that once housed a municipal school system and is currently disabled, is located in the northern portion.

The climate of the region is tropical rainy (AS'); the dry season occurs in October, November, and December and the rainiest seasons are between May and July (NASCIMENTO et al., 2017). The average annual rainfall is $1,651 \mathrm{~mm} /$ year and the average temperature is $25^{\circ} \mathrm{C}$. The soil of the region is classified as dystrophic red yellow argisols (NASCIMENTO et al., 2017). There are signs of anthropization in the area, especially on the north and south banks, seen in the presence of exotic orchard remnants and garbage disposal (NASCIMENTO et al., 2017).

Until 2011, the RA consisted of an open field dominated by Pennisetum purpureum Schum. (elephant grass) and Urochloa decumbens (Stapf) R.D. Webster (brachiaria) planted for pasture (Figure 1b). Under these conditions, no native species from $\mathrm{MC}$ were found. Since 2011, reforestation interventions have been carried out in

FIGURE 1: Location of the study area in the state of Pernambuco (a). The study area (white rectangle) before reforestation in 2010 (b) and after reforestation in 2018 (c).

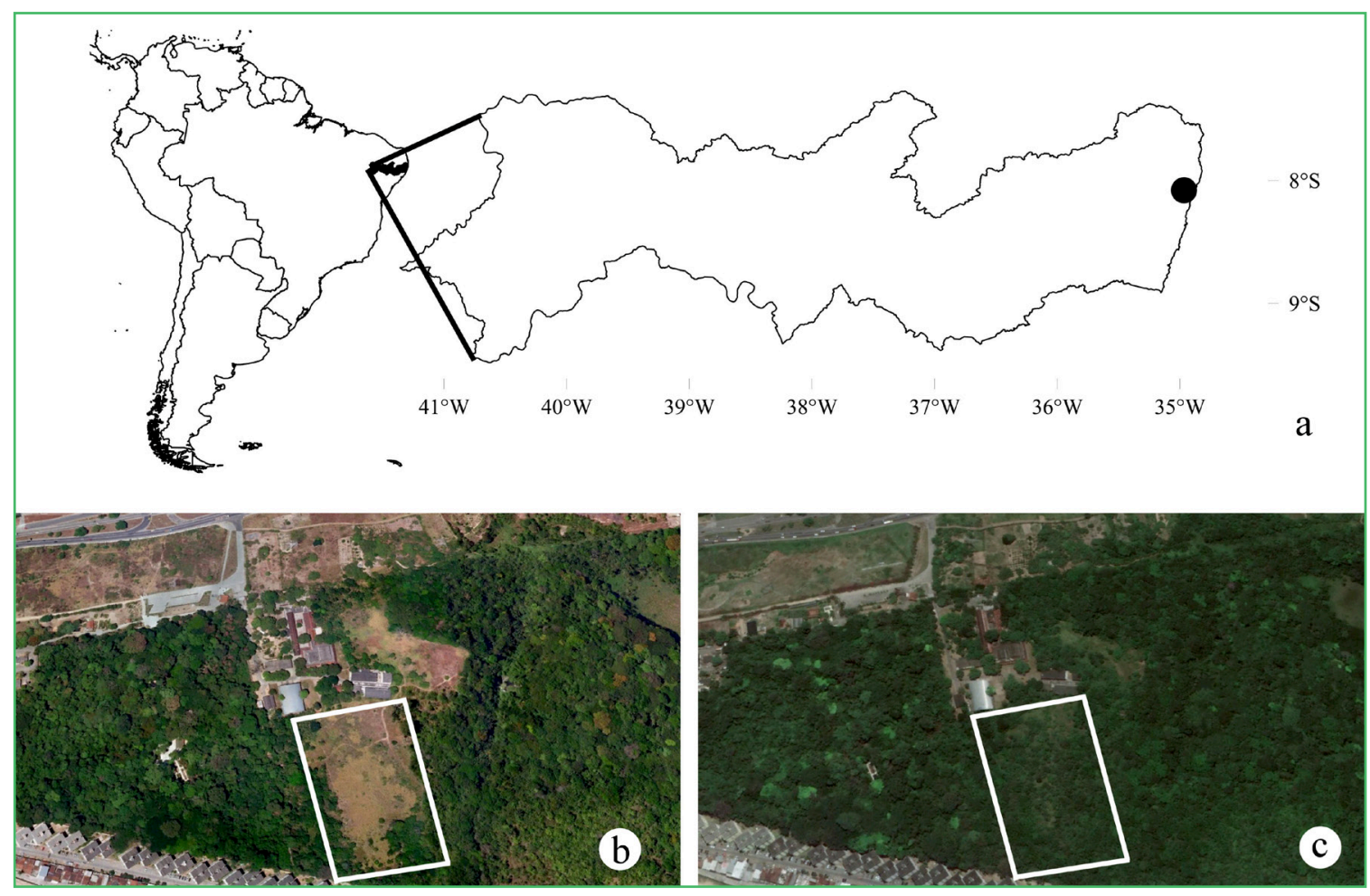


order to connect the fragments of MC through the RA. In this reforestation, native tree species were used, but none of them belonged to Melastomataceae.

\section{Data collection}

Fieldwork was carried out from May 2018 to January 2019 and the collections were monthly. The dehydrated and processed materials were sent to the RB and UFP herbaria (acronyms according to THIERS, 2020). The collections were focused on the species of Melastomataceae. Their identification was based on specialized literature (CHAGAS, 2012; ARAÚJO; LIMA, 2013) and on the comparison of samples deposited in the UFP herbarium as well as with the types available on online platforms of Reflora Virtual Herbarium (http://reflora.jbrj.gov.br/reflora/ herbarioVirtual/) and SpeciesLink (http://www.splink. org.br/).

To compare whether the composition and richness of the RA are similar to that of MC, we also conducted collections on a MC and herbarium survey at the UFP. We complemented with a search on the SpeciesLink digital platform about the Melastomataceae species that occur in MC.

Data on fruit size and type for each species from both reforested and adjacent areas were obtained from taxonomic descriptions (CHAGAS, 2012; ARAÚJO;
LIMA, 2013;) and measures from exsiccatae. In some cases, where there was no description of the fruit size and type in the taxonomic literature, measurements from exsiccates were taken. The classification of species according to dispersal syndrome was based on Van der Pijl (1982) and the successional classification was based on Gandolfi et al. (1995).

\section{Data analysis}

Species composition, richness, and categories were compared by simple descriptive statistics. To compare whether there is a difference in the fruit sizes between reforested and MC areas, a variance analysis and a Krustal-Wallis analysis were performed. Data analyzes were performed using the Past 3.19 software (HAMMER et al., 2001).

\section{Results}

In the MC fragment nine species of Melastomataceae and five species in the RA were found (Table 1). Clidemia capitellata (Bonpl.) D.Don., C. hirta (L.) D.Don., Miconiaaffinis DC., M. albicans (Sw.) Triana, and M. prasina (Sw.) DC. were found in both areas.

The fruits in the RA and MC areas are a fleshy berry type adapted to zoochoric dispersion. In the RA, all species were classified as pioneer (PI), typical of the

TABLE 1: Floristic composition, occurrence, fruit size, fruit type, successional classification and dispersion syndrome of the species inventoried in a reforested area and forest fragments from the Atlantic Forest in Recife, Brazil. MC - UCN- Matas do Curado; RA - reforested area $(0=$ absent; 1 = present $)$; and CS - successive classification (Pioneer - PI; Secondary - SE).

\begin{tabular}{lccccl}
\multicolumn{1}{c}{ Species } & RA & MC & FS & CS & \multicolumn{1}{c}{ Voucher } \\
\hline Clidemia capitellata(Bonpl.) D.Don. & 1 & 1 & $0.7 \mathrm{~cm}$ & PI & Couceiro et al. 19 \\
Clidemia hirta (L.) D.Don. & 1 & 1 & $0.7 \mathrm{~cm}$ & PI & Couceiro et al. 75 \\
Henrrietea succosa(Aubl.) DC. & 0 & 1 & $1.1 \mathrm{~cm}$ & SE & Pereira s.n. (IPA-56843) \\
Miconia affinisDC. & 1 & 1 & $0.6 \mathrm{~cm}$ & PI & Couceiro et al. 46 \\
Miconia albicans (Sw.) Triana & 1 & 1 & $0.5 \mathrm{~cm}$ & PI & Couceiro et al. 02 \\
Miconia holosericea(L.) DC. & 0 & 1 & $1.0 \mathrm{~cm}$ & SE & Pereira s.n. (IPA-56818) \\
Miconia minutiflora (Bonpl.) DC. & 0 & 1 & $0.5 \mathrm{~cm}$ & PI & Correia et al. 11 \\
Miconia prasina(Sw.) DC. & 1 & 1 & $0.5 \mathrm{~cm}$ & PI & Couceiro et al. 45 \\
Pterolepis trichotoma(Rottb.) Cogn. & 0 & 1 & $0.5 \mathrm{~cm}$ & PI & Falcão et al. 770 \\
\hline
\end{tabular}


early stages of natural regeneration. The fruits in the RA are smaller than in the $\mathrm{MC}, 0.6 \mathrm{~cm}$ long and $0.7 \mathrm{~cm}$ long, respectively (Table 1), but there was no statistically significant difference between the means of the two areas $(\mathrm{df}=1, \mathrm{~F}=0.81, \mathrm{p}=0.38)$. Likewise, the medians showed no significant difference $(H=0.26, p=0.59)$.

Figure 2 shows the fruit of the most abundant species in the reforested area.

\section{Discussion}

The results show that the RA already presents expected ecological processes for a corridor between the two adjacent areas, acting as vectors for the colonization of native Atlantic Forest species. Even though the reforested area is smaller and more immature than the adjacent areas, the composition of native elements expected for phytophysiognomy is being established by natural processes.

All five Melastomataceae species found in the RA are categorized as pioneers, as expected for early regeneration stages in the Atlantic Forest (LIEBSCH et al., 2008). Pioneer species predominate in recently disturbed ecosystems (OLIVEIRA et al., 2004;
TABARELLI et al., 2004). Liebsch et al. (2008) suggest that an Atlantic Forest patch needs 157 years for nonpioneer species to predominate. When we conducted the survey of Melastomataceae species the RA had presented less than 10 years of reforestation.

None of the species analyzed have anemochoric dispersion. The fruit morphology indicates that these species are consumed by animals which have been acting as dispersal vectors. This is reinforced by the fact that several genera of Melastomataceae are part of the diet of various animal groups (PONTES; SOARES, 2005; MARUYAMA et al., 2007; BARCELOS et al., 2013; ALVES, 2014; REGINATO et al., 2020). In addition, Melastomataceae has functional attributes that make species attractive to frugivorous animals, such as a large amount of fruit per plant and nutritional availability (MARUYAMA et al., 2007).

Birds are among the main dispersers of the Melastomataceae species, which may contribute differently to the quality and quantity of seed dispersal components (LOISELLE; BLAKE, 1999). Thus, different bird species may participate in some stages of dispersal, but not contribute equally in the process. For example, Ellison et al. (1993) observed that plant

FIGURE 2: Fruit of the most abundant species found in the RA. A. Clidemia hirta. B. Miconia albicans. C. Miconia prasina.
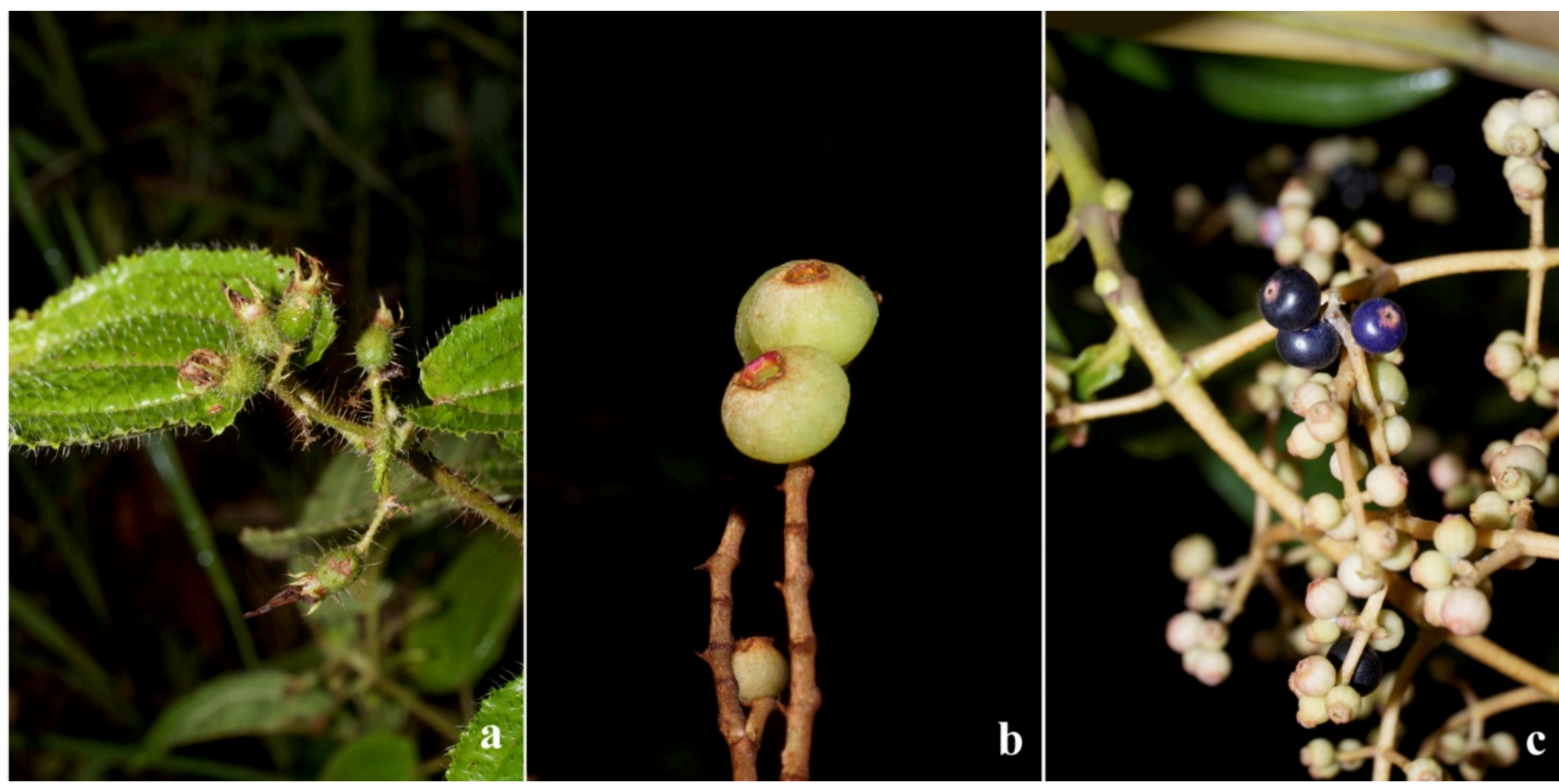
species from more open and bright environments tend to have a higher and faster germination rate when they pass through the digestive tract of birds than plant species from shaded environments. This pattern could explain the absolute predominance of the pioneer species of Melastomataceae in the area, even when considering that in adjacent fragments typical species of shaded environments can be found.

Some of the records of this relationship between fruit-eating birds and Melastomataceae species may be analogous to the events that are probably occurring in the RA. In a submontane rainforest fragment in northeastern Brazil, C. hirta and M. affinis were reported as part of the diet of the bird Chiroxiphia pareola Linnaeus, 1766 (ALVES, 2014). The $C$. pareola has populations in MC (PEREIRA et al., 2011). In a fragment of lowland Atlantic Forest in southeastern Brazil, two species of thrush (Turdus albicollis Vieillot, 1816 and Turdus amaurochalinus Cabanis, 1850) were found ingesting fruits and dispersing seeds of M. prasina (ALVES et al., 2008). Turdus amaurochalinus Cabanis, 1850 has been identified as one of the omnivorous avifauna species in forests adjacent to the regenerating area (PEREIRA et al., 2011).

In addition to birds, mammals also include the Melastomataceae species in their diets (REGINATO et al., 2020). The most correlated example of what is happening in the area is the record of a population of Callithrix jacchus Linnaeus, 1758 (White-tufted marmoset) from Dois Irmãos State Park using $M$. prasina in their diet, with the intake of the fruit gum (PONTES; SOARES, 2005). Notably, M. prasina is the most abundant species in the study area and with one of the largest fruits among the species studied. Similarly, the white-tufted marmoset has a particularly large population in the area, and it is easy to see that the various groups formed by moving and consuming the fruits of this and other species.

Fragmentation and urbanization of the northeastern Atlantic Forest caused an intense defaunation process of the region's relatively small and impoverished remnants (CANALE et al., 2012; GARBINO et al., 2018). However, our results provide a glimmer of hope for conservation of the region by demonstrating that natural processes can be reestablished in the northeastern Atlantic Forest.

\section{Acknowledgments}

We are grateful to the Prefeitura da Cidade do Recife for granting the first author' fellowship. We thank the managers of Jardim Botânico do Recife for logistical support. We are thankful for the translator Petrison de Veras Martins' understanding and availability. We also thank the two anonymous reviewers for their suggestions, that have improved the present paper.

\section{References}

ALVES, A. S. Frugivoria e dispersão de sementes por Chiroxiphia pareola (Pipridae) em um brejo de altitude, Nordeste do Brasil. 2014. 35 f. Monografia (Bacharelado em Ciências Biológicas) Universidade Federal da Paraíba, Areia. 2014.

ALVES, M. A. S.; RITTER, P. D.; ANTONINI, R. D.; ALMEIDA, E. M. Two thrush species as dispersers of Miconiaprasina (Sw.) DC. (Melastomataceae): an experimental approach. Brazilian Journal of Biology, São Carlos, v. 68, p. 397-401, 2008.

ARAÚJO, C. M. L. R.; LIMA, R. B. Melastomataceae na Área de Proteção Ambiental Tambaba, Litoral Sul da Paraíba, Brasil. Rodriguésia, Rio de Janeiro, v. 64, n. 1, p. 137-149, 2013.

BACCI, L. F.; AMORIM, A. M.; MICHELANGELI, F. A.; GOLDENBERG, R. Increased sampling in under-collected areas sheds new light on the diversity and distribution of Bertolonia, an Atlantic Forest endemic genus. Systematic Botany, Laramie, v. 43, n. 3, p. 767-792, 2018.

BARCELOS, A. R.; BOBROWIEC, P. E.; SANAIOTTI, T. M.; GRIBEL, R. Seed germination from lowland tapir (Tapirus terrestris) fecal samples collected during the dry season in the northern Brazilian Amazon. Integrative Zoology, Beijing, v. 8, p. 63-73, 2013.

BFG - THE BRAZIL FLORA GROUP. Growing knowledge: an overview of seed plant diversity in Brazil. Rodriguésia, Rio de Janeiro, v. 66, p. 1085-1113, 2015.

CANALE, G. R.; PERES, C. A.; GUIDORIZZI, C. E.; GATTO, C. A. F.; KIERULFF, M. C. M. Pervasive defaunation of forest remnants in a tropical biodiversity hotspot. PloS One, Cambridge, v. 7, p. 41671, 2012.

CAVALCANTI, D. M. F.; AMORIM, B. S.; MACIEL, J. R.; ALVES, M. Checklist from an Atlantic Forest vegetation mosaic in Reserva Particular do Patrimônio Natural Fazenda Tabatinga, Pernambuco, Brazil. CheckList, Rio Claro, v. 12, n. 6, 2016.

CHAGAS, E. C. O. O gênero Miconia Ruiz \&Pav. (Melastomataceae) na Floresta Atlântica do Nordeste Oriental. 2012. 115 f. Dissertação (Mestrado em Biologia Vegetal) Universidade Federal de Pernambuco, Recife. 2012. 
ELLISON, A. M.; DENSLOW, J. S.; LOISELLE, B. A. Seed and seedling ecology of neotropical Melastomataceae. Ecology, New York, v. 74, p. 1733-1749, 1993.

FAHRIG, L. Effects of habitat fragmentation on biodiversity. Annual Review of Ecology, Evolution, and Systematics, Palo Alto, v. 34, p. 487-515, 2003

FLORA DO BRASIL Melastomataceae in Flora do Brasil 2020 em construção. 2020. Available in: <http://floradobrasil.jbrj.gov. br/reflora/floradobrasil/FB161>.

GANDOLFI, S.; LEITÃO FILHO, H. D. F.; BEZERRA, C. L. F. Levantamento florístico e caráter sucessional das espécies arbustivo-arbóreas de uma floresta mesófila semidecídua no município de Guarulhos, SP. Revista Brasileira de Biologia, São Carlos, v. 55, p. 753-767, 1995.

GARBINO, G. S. T.; REZENDE, G. C.; FERNANDESFERREIRA, H.; FEIJÓ, A. Reconsidering mammal extinctions in the Pernambuco Endemism Center of the Brazilian Atlantic Forest. Animal Biodiversity and Conservation, Barcelona, v. 41, p. 175184, 2018.

GOLDENBERG, R.; BAUMGRATZ, J. F. A.; SOUZA, M. L. D. R. Taxonomia de Melastomataceae no Brasil: retrospectiva, perspectivas e chave de identificação para os gêneros. Rodriguésia, Rio de Janeiro, v. 63, p. 145-161, 2012.

HAMMER, Ø.; HARPER, D. A. T.; RYAN, P. D. PAST: Paleontological Statistics Software package for education and data analysis. Palaeontologia Electronica, Oslo, v. 4, n. 1, p. 1-9, 2001. LIEBSCH, D.; MARQUES, M. C. M.; GOLDENBERG, R. How long does the Atlantic Rain Forest take to recover after a disturbance? Changes in species composition and ecological features during secondary succession. Biological Conservation, Boston, v. 141, n. 6, p. 1717-1725, 2008.

LOISELLE, B. A.; BLAKE, J. G. Dispersal of melastome seeds by fruit-eating birds of tropical forest understory. Ecology, New York, v. 80, p. 330-336, 1999.

MARUYAMA, P. K.; ALVES-SILVA, E.; MELO, C. Oferta qualitativa e quantitativa de frutos em espécies ornitocóricas do gênero Miconia (Melastomataceae). Revista Brasileira de Biociências, Porto Alegre, v. 5, p. 672-674, 2007.

MELO, A.; AMORIM, B. S.; GARCÍA-GONZÁLEZ, J.; SOUZA, J. A. N. de; PESSOA, E. M.; MENDONÇA, E. de; CHAGAS, M.; ALVES-ARAÚJO, A.; ALVES, M.Updatedfloristicinventoryofthe angiospermsofthe Usina São José, Igarassu, Pernambuco, Brazil. Revista Nordestina de Biologia, João Pessoa, v. 20, n. 2, p. 3-26, 2011.

MITTERMEIER, R. A.; MITTERMEIER, C. G.; BROOKS, T. M.; PILGRIM, J. D.; KONSTANT, W. R.; FONSECA, G. A. B.; KORMOS, C. Wilderness and biodiversity conservation. Proceedings of the National Academy of Sciences of the United States of America, Washington, v. 100, p. 10309-10313, 2003.
MYERS, N.; MITTERMEIER, R. A.; MITTERMEIER, C. G.; FONSECA, G. A. B. da; KENT, J. Biodiversity hotspots for conservation priorities. Nature, London, v. 403, p. 853-858, 2000.

NASCIMENTO, L. M.; OLIVEIRA, A. M.; NASCIMENTO, B. U. do. Aspectos históricos e ambientais do Jardim Botânico do Recife, Pernambuco. Arrudea, Recife, v. 3, p. 51-75, 2017.

OLIVEIRA, M. A.; GRILLO, A. S.; TABARELLI, M. Forest edge in the Brazilian Atlantic forest: drastic changes in tree species assemblages. Oryx, Cambridge, v. 38, n. 4, p. 389-394, 2004.

PEREIRA, G. A.; PERIQUITO, M. C.; BRITO, M. T.; MENEZES, M. Estrutura trófica da avifauna no Jardim Botânico do Recife, Pernambuco, Brasil. Atualidades Ornitológicas, Ivaiporã, v. 164, p. 57-63, 2011.

PONTES, A. R. M.; SOARES, M. L. Sleeping sites of common marmosets (Callithrix jacchus) in defaunated urban forest fragments: a strategy to maximize food intake. Journal of Zoology, London, v. 266, p. 55-63, 2005.

REGINATO, M.; VASCONCELOS, T. N.; KRIEBEL, R.; SIMÕES, A. O. Is dispersal mode a driver of diversification and geographical distribution in the tropical plant family Melastomataceae? Molecular Phylogenetics and Evolution, New York, v. 148, 106815, 2020.

REZENDE, C. L.; SCARANO, F. R.; ASSAD, E. D.; JOLY, C. A.; METZGER, J. P.; STRASSBURG, B. B. N.; MITTERMEIER, R. A. From hotspot to hotspot: an opportunity for the Brazilian Atlantic Forest. Perspectives in Ecology and Conservation, São Paulo, v. 16, p. 208-214, 2018.

RIBEIRO, M. C.; METZGER, J. P.; MARTENSEN, A. C.; PONZONI, F. J.; HIROTA, M. M. The Brazilian Atlantic Forest: how much is left, and how is the remaining forest distributed? Implications for conservation. Biological Conservation, Boston, v. 142, p. 1141-1153, 2009.

TABARELLI, M.; DA SILVA, J. M. C.; GASCON, C. Forest fragmentation, synergisms and the impoverishment of neotropical forests. Biodiversity \& Conservation, New York, v. 13, n. 7, p. 1419-1425, 2004.

TABARELLI, M.; MELO, M. D. V. C.; LIRA, O. C. Os estados da Mata Atlântica: Nordeste. In: CAMPANILI, M.; PROCH NOW, M. (Ed.). Mata Atlântica uma rede pela floresta. Brasília: RMA, 2006. p. 149-164.

TABARELLI, M.; PERES, C. A. Abiotic and vertebrate seed dispersal in the Brazilian Atlantic forest: implications for forest regeneration. Biological Conservation, Boston, v. 106, p. 165-176, 2002.

THIERS, B. [continuously updated] Index Herbariorum: a global directory of public herbaria and associated staff. 2020. New York: New York Botanical Garden's Virtual Herbarium. Available in: $<$ http://sweetgum.nybg.org/science/ih/>.

VAN DER PIJL, L. Principles of dispersal. Berlin: Springer Verlag, 1982. $214 \mathrm{p}$. 